\title{
ResearchArticle
}

\section{Morphotaxonomy of powdery mildew fungus (Golovinomyces cichoracearum DC) on Helianthus petiolaris}

\author{
Rahul Kumar Tiwari, R.K. Sharma and Ashish Kumar Singh
}

\section{SUMMARY}

The powdery mildew disease caused by Golovinomyces cichoracearum on Helianthus petiolaris recorded for the first time from New Delhi, India. The symptoms of disease appeared in the first week of March on the upper surface of leaves and then on other green parts of the plant. The development of few cleistothecia on the upper surface of leaves was also observed in the last week of April, when conidial production was slowed down and ceased. The infected plants remained stunted due to reduction in size and number of the leaves. Although the host range of powdery mildew caused by Golovinomyces cichoracearum has been previously described, no full description and illustration of the infection, including symptoms and signs on Helianthus petiolaris, has yet appeared. This is the first description of powdery mildew on Helianthus petiolaris, featuring taxonomic identification, symptoms, and signs.

Key Words : Chasmotheca, Golovinomyces, Fibrosin body, Ascomata

How to cite this article : Tiwari, Rahul Kumar, Sharma, R.K. and Singh, Ashish Kumar (2018). Morphotaxonomy of powdery mildew fungus (Golovinomyces cichoracearum DC) on Helianthus petiolaris. Internat. J. Plant Sci., 13 (1): 22-25, DOI: 10.15740/HAS/IJPS/13.1/22-25.

Article chronicle : Received : 13.05.2017; Revised : 07.11.2017; Accepted : 21.11.2017

\section{$\longrightarrow$ MEMBERS OF THE RESEARCH FORUM}

Author to be contacted :

Rahul Kumar Tiwari, Division of Plant Pathology, IARI, New Delhi (India)

Email : rahultiwari226@gmail.com

Address of the Co-authors:

R.K. Sharma, Division of Plant Pathology, IARI, New Delhi (India)

$\overline{\text { Ashish Kumar Singh, Division of Nematology, IARI, New Delhi }}$ (India) 